working plans for the forestry areas under his charge. His gazetted staff, though small, were well trained to undertake the work. The consequence is that in the present report the conservator can write, "Almost all the Forest Reserves are now governed by Working Plans, under which some form of elementary yield control has been introduced : owing to recent increase in sawmills and demand for local timber more intensive yield control will be required in some areas in the near future. So far as the improvement of the growing stock is concerned the silvicultural programme now provides for an average regeneration of approximately 550 acres per annum, whilst the total area of completed regeneration amounts to 3,958 acres. Further expansion of the rate of regeneration of indigenous species can be effected when the shortage of charcoal burners and labourers, caused by the U.S.A. bases, comes to an end."

With reference to the position of working plans in the Forest Department under the Colonial Office, it would place the actual position in a stronger light if some of the most detailed plans could be printed and circulated within the British Empire. The nature of the working plans themselves and their general drafting and proposals would thus be available to other departments and their forest officers. On the subject of utilization, for some years the exploitation of the mora forests, in which this species grows to some extent gregariously over about half the total area of forest in Trinidad, has been contemplated, but it is said that the difficulties of exploiting these areas have not yet been surmounted owing to an accumulation of checks caused by war conditions.

The utilization of both local and imported lumber is extremely wasteful, says the conservator, avoidable losses by fungus and termite attack, owing to lack of precautionary measures, being very high. The Colony is also still dependent on large supplies of imported softwoods, mainly pitch pine, white pine and Douglas fir, apart from the special demand created by war conditions. It may be asked whether this failure to open out the mora forests and to check wasteful exploitation may not be due to the smallness of the forest staff of the Colony, in view of the growing work under the Department.

\section{LOCATION OF THUNDERSTORMS BY RADIO METHODS}

$\mathrm{M}$

ANY investigators in various parts of the world have used radio receiving equipment to study atmospheric disturbances, their wave-form, nature and origin. It is clear from this work that such atmospherics arise from electrical disturbances in the atmosphere, and mainly if not entirely from actual lightning flashes. The results of such investigations have been applied to some extent by the electrical engineer in connexion with the breakdown of overhead line power distribution systems. In Great Britain lightning is responsible for a large proportion of such breakdowns, and if means could be available to give adequate warning of the presence of a thunderstorm in a particular area, certain steps can be taken by operating engineers to reduce the probability and extent of interruptions of electrical supply. A contribution to this aspect of the subject has recently been provided in a paper entitled "The Determination of the Location and Frequency of
Thunderstorms by a Radio Method" by Mr. J. S. Forrest, read before the Royal Meteorological Society on November 18 last.

Previous investigators had shown that there was some correlation between the field strength of atmospherics and the distance of the source, but further knowledge was required to put this on a sufficiently definite basis for practical use. Moreover, further investigations were required in order to ensure that the atmospheric disturbances recorded emanated from, or were at least uniquely associated with, lightning strokes to ground, which are the cause of breakdown of high-voltage electrical systems. The equipment used in the present work has been previously described by the author, and consists essentially of a mains-operated radio receiver tuned to approximately $150 \mathrm{kc}$./sec. (wave-length 2,000 m.), the output from which is applied to a commercial type moving-coil pen-recorder marking continuously on a paper chart. Provision is made for maintaining the overall sensitivity of the receiver constant, so that it can be operated twenty-four hours a day for months at a time. An ordinary outdoor aerial is used of length about $20 \mathrm{~m}$., and it was found that a fullscale deflexion on the recorder chart corresponded to a peak field-strength of between one and two millivolts per metre, indicating the presence of a thunderstorm within $16 \mathrm{~km}$. of the instrument.

The present paper gives the results of three years experience with this technique. The first equipment was installed at a station in Surrey in 1939, and other instruments have been brought into use in Wiltshire and Northumberland; and all three are now in continuous operation. Samples of the charts showing thunderstorm records accompany Mr. Forrest's paper, and the times of occurrence of overhead line breakdowns are shown thereon, to illustrate the correlation between the distance of a storm and the recorded atmospherics resulting from it.

The characteristics of breakdown caused by lightning on overhead power systems are well known, and the exact location can be determined when the line or substation is afterwards inspected. Thus power supply system statistics provide reliable evidence of the location and time of occurrence of lightning strokes to ground; and this type of information has accordingly been used by the author to obtain the relation between atmospherics recorder output and distance of the storm. Considerable variations are to be expected in this relationship, having regard to such facts as that the storm may cover a considerable area, and while the nearer portions may give rise to the strongest atmospherics recorded, the more remote parts of the storm may be the cause of the breakdown. A study of the results obtained over the full year 1941, however, indicates that the maximum field strength of the atmospherics recorded is approximately inversely proportional to the square root of the distance of the lightning constituting the source.

This type of knowledge has been applied with some success to give a warning of the approach of a thunderstorm to a particular area. For example, if it is desired to forecast the occurrence of storms within a radius of $60 \mathrm{~km}$., a warning might be given when the atmospherics record indicates the presence of a storm within $160 \mathrm{~km}$. Apparently thunderstorms seldom move faster than $50 \mathrm{~km}$./hour, so that two or three hours may be expected to elapse before the outbreak of a storm; and this is in accordance with results which have been obtained in practice. 
With three instruments distributed as already indicated, some storms have been recorded simultaneously at each site, and thus a location of the source has been obtained. It is frequently not possible, however, to locate in this way the widespread storms which are common in summer, as the extent of the storm is often of the same order as its distance from the recording instrument. Experience indicates that the records of a single instrument provide ample warning of the occurrence of a storm in the district; and the author appears to doubt whether it is worth while to use, for this purpose, several instruments with the necessary telephone communication facilities between the sites.

The later portions of the paper point out that the recording apparatus set up for the above application may also be used to obtain a permanent and objective record of thunderstorm activity over certain areas ; and a comparison is made between such records and the statistics on the frequency of thunderstorms obtained from observers' reports. Diagrams in the paper indicate typical diurnal variations of atmospherics and the general contrast between summer and winter conditions. In the winter months, there is relatively little variation in intensity throughout the twenty-four hours; whereas in the summer, the intensity is on the whole much greater, with a pronounced maximum in the afternoon between 1500 and 1600 G.M.T. In conclusion, it is worth remarking that for storms within the range of the instrument, the rate at which lightning flashes are recorded has been found to vary from seven per hour to eighty per hour, the lower rate being associated with winter storms.

\section{FORTHCOMING EVENTS \\ (Meeting marked with an asterisk is open to the public)}

\section{Saturday, March 6}

Grologists' Association (at the Geological Society of London, GroLOGISTS Associccadilly, London, W.1), at 2.30 p.m.- Annual Burlington House, Piccadill, ead, F.R.S.: "Meditations on Granite" (Presidential Address).

\section{Saturday, March 6-Sunday, March 7}

INSTITUTE OF INDUSTRIAL ADMINISTRATION (at the Waldorf Hotel ldwych, London, W.C.2). Conference on "Training for Industria? Management"."

Saturday, March 6

10 a.m.-Management and the Nation.

11.15 a.m.-Address by His Grace the Lord Archbishop of Canterbury.

12.30 p.m.-Management and Industry.

3 p.m.-External Training for Industry.

5.30 p.m.- Internal Training in Industry.

Sunday, March 7

10 a.m.-Management and the Board Room.

11.30 a.m.-Review of Conference.

\section{Monday, March 8}

ROYal GROGRAPHICAL SocteTy (at Kensington Gore, London, ROYAL GEOGRAPHIjALeer Wibo Peekema : "Javanese Colonization of Sumatra",

\section{Wednesday, March 10}

ROYAL SOCIETY OF ARTS (at John Adam Street, Adelphi, London W.C.2), at 1.45 p.m.-Miss M. Digby: "Agriculture To-day and To-morrow", 6 : "Co-operation as a Factor in Agricultural Stability".

Friday, March 12

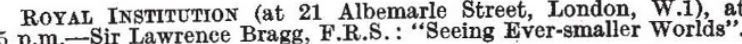

\section{APPOINTMENTS VACANT}

APPLICATIONS are invited for the following appointments on or before the dates mentioned :

Lecturer in Civil and Mrchanicat Eivginegring-The Principal, Huddersfleld Technical College, Huddersfleld (March 15).

LEOTURER IN ELECTRICAI ENGINEERING in the Oxford Schools of Technology, Art and Commerce-The Chief Education Officer, 77 George Street, Oxford (March 15).

TEACHER OF MECHANICAL ENGINEERING SUBJECTS, and a Teacher of Mathematios and/or Science-The Principal, Luton Technical College, Park Square, Luton, Beds. (March 15).

VETERINARY INVESTIGation OFFICER for the Aberystwyth Advisory Province-The Principal, University College of Wales, Aberystwyth (March 20).

Teacher of Mechanical Engineering - The Principal, Wolverton Technical College, Wolverton, Bucks. (March 22).

SoIende Assistant to assist In THE Laboratories-The Acting Headmistress, County School for Girls, Beaverwood Road, Perry Street, Chislehurst, Kent.

LeCTURER IN ChemistrY-The Secretary, Woolwich Polytechnic, Woolwich, London, S.E.18.

\section{REPORTS and other PUBLICATIONS} (not included in the monthly Books Supplement)

\section{Great Britain and Ireland}

Medical Research Council: Committee on the Care of Shipwrecked Personnel. A Guide to the Preservation of Life at Sea after Shipwreck. (M.R.C. War Memorandum No. 8.) Pp. 22, (London: H.M. Stationery Office.) $4 d$. net. [201

Geological Survey of Great Britain : England and Wales. Wartime Pamphlet No. 31: Some Refractory Materials in North-Eastern England. By R. G. Carruthers and W. Anderson. Pp. 19. (London : Geological Survey and Museum.) 18.

Experimental Researches and Reports published by the Department of Glass Technology, The University, Sheffield. Vol. 24, 1941. 78. 6d. [211 Department of Scientific and Industrial Research. Index to the Literature of Food Investigation. Vol. 14, No. 1, June 1942. Compiled by Agnes Elisabeth Glennie assisted by Catherine Alexander. Pp.
iv +72 . (London: H.M. Stationery Office.) 48. 6d. net.
[271

\section{Other Countries}

Bulletin of the American Museum of Natural History. Vol. 80, Art. 8: A Second Supplement to the American Land and FreshWater Isopod Crustacea. By Willard G. Van Name.) Pp. 299-320.
(New York: American Museum of Natural History.)
[201 Annals of the New York Academy of Sciences. Vol. 43, Art. 5 : The Ultracentrifuge. By D. A. MacInnes, W. J. Archibald, J. W. Beams, W. B. Bridgman, Alexandre Rothen and J. W. Williams. Pp. 173-251. (New York: New York Academy of Sciences.) [211
[Ne U.S. Department of Agriculture. Technical Bulletin No. 834 : Morphology and Composition of some Soils of the Miami Family and the Miami Catena. By Irwin C. Brown and James Thorp. Pp. 55. Bulletin of the American Museum of Natural History. Vol. 80, Art. 7: Results of the Archbold Expeditions, No. 47: Review of the Vespertilionine Bats, with special attention to Genera and Species of the Archbold Collections. By G. H. H. Tate. Pp. 221-298. (New
York: American Museum of Natural History.)
[211 York: American Museum of Natural History.)
League of Nations: Economic Intelligence Service. Wartime Rationing and Consumption: (Publication 1942.II.A.2). Pp. 87. Geneva - League of Nations: London: George Allen and Unwin, Ltd.) $3 s .6 d$. $[221$

Pushkin : a Collection of Articles and Essays on the Great Russian Poet A. S. Pushkin. Pp. $188+79$ plates. (Moscow : U.S.S.R. Society for Cultural Relations with Foreign Countries.)

Smithsonian Miscellaneous Collections. Vol. 103, No. 8: The 1914 Tests of the Langley 'Aerodrome'. By C. G. Abbot. (Publicatic Pp. ii + 8, (Washington, D.C.

U.S. Office of Education: Federal Security Agency. Bulletin 1942, No. 1: Opportunities for the Preparation of Teachers in Health Education; a Survey of 20 Teachers Colleges. By Dr. Earl E. Kleinschmidt. Pp. viit 117. (Washington, D.C.: Government Printing Office.) 20 cents.

Proceedings of the United States National Museum. Vol, 92, No 3148: Osteology of Polyglyphanodon, an Upper Cretaceous Lizard from Utah. By Charles W. Gilmore. Pp. 229-266 + plates 24-26. Vol, 92, No. 3149: Notes and New Species of Microlepidoptera from Washington State. By J. F. Gates Clarke. Pp. 267-276 + plates 27-32. Vol. 92, No. 3150: The Genotypes of some of Ashmead's Genera of Ichneumon-Flies. By R. A. Cushman. Pp. 277-290. (Washington,
[2.C. Government Printing Office.)

Bulletin of the Madras Government Museum. New Series, General Section, Vol. 4: Amaravati Sculptures in the Madras Government Section, Vol. 4: Amaravati Sculptures in the Madras Government Museum. By C. Sivaramamurti. Pp. xviii $+376+65$ plates. (Madras :
Government Press.) $14 \cdot 8$ rupees. Indian Forest Records (New Series). Botany, Vol. 3, No. 7: A Sketch of the Flora of the Bailadila Range in Bastar State. By $\mathrm{F}$. F. Mooney. Pp. iv +197-253. (Delhi: Manager of Publications.) 2.6 rupees ; 48 . 